OPEN ACCESS

Edited by:

Gregoire P. Millet,

University of Lausanne, Switzerland

Reviewed by:

Edward McAuley,

University of Illinois at

Urbana-Champaign, USA

Neha Lodha,

University of Florida, USA

Bradley Fawver,

University of Florida, USA

${ }^{*}$ Correspondence:

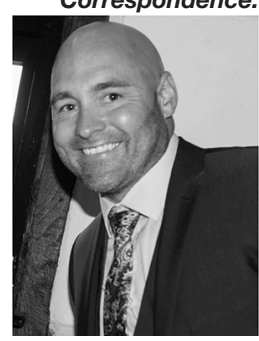

Lee Taylor, formerly a UK based research active academic, is now a Research Scientist at Aspetar, an Orthopaedic and Sports Medicine Hospital in Doha, Qatar. His research focuses on exercise, cognition, and

heat shock proteins in extreme environments and their relationship with exercise/sporting performance,

occupational activities (e.g., the military), and clinical practice. He has completed externally funded research for prestigious organizations such as

FIFA and UEFA, and currently has surgical clinical collaborations ongoing within the National Health Service

(NHS) in the UK. Current research projects are seen within Elite team and individual sports, including ultra-endurance based exercise (most recently the 2015 Marathon Des

Sables).

lee.taylor@aspetar.com

\section{The Impact of Different Environmental Conditions on Cognitive Function: A Focused Review}

\author{
Lee Taylor ${ }^{1,2 *}$, Samuel L. Watkins ${ }^{2}$, Hannah Marshall ${ }^{2}$, Ben J. Dascombe ${ }^{3}$ and \\ Josh Foster ${ }^{2}$
}

' Athlete Health and Performance Research Centre, ASPETAR, Qatar Orthopaedic and Sports Medicine Hospital, Doha, Qatar, ${ }^{2}$ Applied Sport and Exercise Physiology Research Group, Department of Sport Science and Physical Activity, Institute for Sport and Physical Activity Research, University of Bedfordshire, Bedford, UK, ${ }^{3}$ Applied Sport Science and Exercise Testing Laboratory, Faculty of Science and Information Technology, University of Newcastle, Ourimbah, NSW, Australia

Cognitive function defines performance in objective tasks that require conscious mental effort. Extreme environments, namely heat, hypoxia, and cold can all alter human cognitive function due to a variety of psychological and/or biological processes. The aims of this Focused Review were to discuss; (1) the current state of knowledge on the effects of heat, hypoxic and cold stress on cognitive function, (2) the potential mechanisms underpinning these alterations, and (3) plausible interventions that may maintain cognitive function upon exposure to each of these environmental stressors. The available evidence suggests that the effects of heat, hypoxia, and cold stress on cognitive function are both task and severity dependent. Complex tasks are particularly vulnerable to extreme heat stress, whereas both simple and complex task performance appear to be vulnerable at even at moderate altitudes. Cold stress also appears to negatively impact both simple and complex task performance, however, the research in this area is sparse in comparison to heat and hypoxia. In summary, this focused review provides updated knowledge regarding the effects of extreme environmental stressors on cognitive function and their biological underpinnings. Tyrosine supplementation may help individuals maintain cognitive function in very hot, hypoxic, and/or cold conditions. However, more research is needed to clarify these and other postulated interventions.

\section{Keywords: cognitive function, cognition, heat, cold, altitude, hypoxia, environment}

\section{INTRODUCTION}

Cognitive function defines performance in objective tasks that require conscious mental effort (Lamport et al., 2014). Such tasks include memory (verbal, spatial, and working), attention, and executive function (Lezak, 2004). These tasks are often categorized as either "simple" or "complex" (Ramsey and Kwon, 1992); simple tasks are those which require very simple perceptual motor skills

Abbreviations: ${ }^{\circ} \mathrm{C}$, Degrees Celsius; 5-HT, 5-hydroxytryptamine; ANT, Attention Network Test; DA, Dopamine; DHEA, Dehydroepiandrosterone; fMRI, Functional Magnetic Resonance Imaging; m, Meter; min, Minutes; ms, Millisecond; $\mathrm{O}_{2}$, Oxygen; $\mathrm{PaO}_{2}$, Partial Pressure of Oxygen; r.h., Relative Humidity; $T_{C}$, Core Temperature; TRPM8, Transient Receptor Potential Melastatin 8; $T_{S K}$, Skin Temperature; WADA, World Anti-Doping Agency. 
(e.g., choice reaction time, memory recall), whereas complex tasks require a greater effort and/or attention, such as multiple/dual tasks [e.g., complex motor coordination, working memory tasks (Bradley and Higenbottam, 2003)]. However, categorization of cognitive tasks remains somewhat problematic as each task activates different regions of the brain (Qian et al., 2013) and individual familiarity with the task(s) may alter task classification. Based on previous literature (Gopinathan et al., 1988; Ramsey and Kwon, 1992; Bradley and Higenbottam, 2003; Hancock and Vasmatzidis, 2003; Gaoua, 2010) Table 1 provides a breakdown of which tasks are categorized as "simple" and "complex"-this review article will adhere to this classification. This categorization approach is recognized as simplistic and is utilized to aid readability of the presented Focused Review, with the caveat that readers should interpret this classification with care.

It is clear from previous work that different environmental conditions can negatively impact cognitive function. Past research has shown that hot (Hocking et al., 2001; Bandelow et al., 2010; Morley et al., 2012; Parker et al., 2013), cold (Marrao et al., 2005; Mäkinen et al., 2006; Adam et al., 2008a; Spitznagel et al., 2009; Muller et al., 2012; Taylor et al., 2014), and hypoxic (Kourtidou-Papadeli et al., 2008; de Aquino Lemos et al., 2012; Muller et al., 2012; Ando et al., 2013; Neuhaus and Hinkelbein, 2014) exposures can impair these cognitive processes in humans, and it appears that a combination of interrelated psycho-physiological pathways may be responsible for these deficits (as will be subsequently be reviewed). Moreover, we will discuss the pathways responsible for such cognitive alterations, relevant interventional strategies which may acquiesce these deficits, and finally recommendations for future research.

\section{TEMPERATURE AND COGNITIVE FUNCTION}

\section{Heat Stress}

Heat stress is recognized as an occupational hazard within the scientific literature, often attributed to compromised cognitive function (Ramsey et al., 1983; Tawatsupa et al., 2013). For

TABLE 1 | Categorization of simple and complex cognitive tasks.

\begin{tabular}{ll}
\hline Simple cognitive tasks & Complex cognitive tasks \\
\hline Mental transformation & Arithmetic efficiency \\
Monitoring & Attention \\
Memory recall & Complex motor coordination \\
Numerical vigilance & Dual tasks \\
Choice reaction time & Executive function \\
Short term memory & Mental addition \\
Simple arithmetic & Recall capacity \\
Simple visual orientation & Sustained attention \\
& Tracking \\
& Vigilance \\
& Visual motor tracking \\
& Working memory tasks
\end{tabular}

example, when 17,000 safety observations were made over a 14 month period in factory workers, the relationship between the ambient temperature and unsafe behaviors formed a Ushaped curve. Specifically, minimum unsafe behaviors occurred when the ambient temperature was between 17 and $23^{\circ} \mathrm{C}$, whereas temperatures outside of this range saw increasing unsafe behaviors displayed (Ramsey et al., 1983). Utilizing logistic regression (heat stress and occupational injury), it was demonstrated that $\sim 20 \%$ of Taiwanese workers $(n=58.495)$ experienced occupational heat stress, which was strongly and significantly associated with workplace accident rates (Tawatsupa et al., 2013). The notion that indoor workers are generally sufficiently protected via air conditioning, fans, or other cooling systems does not apply to most industrial workplaces in low and middle income countries, that are located in hot regions of the world (Balakrishnan et al., 2010).

Occupations at risk of extreme heat exposure may include mining, shearing, farming, factory work, firefighting, and other emergency/military services (Arbury et al., 2014). Performing occupational tasks in close proximity to heat-generating equipment can also generate exceptionally hot environments. Additionally, several occupations (e.g., firefighting, chemical waste, and bomb disposal) require workers to wear impermeable protective clothing, which interferes with evaporative heat loss mechanisms and may overwhelm the ability of this primary heat loss effector system to maintain core temperature $\left(T_{c}\right)$ at $\sim 37^{\circ} \mathrm{C}$ (Cheung et al., 2000; Armstrong et al., 2010).

Examining the relationship between heat stress and cognitive function is a challenging task as there are many confounding factors that may have influenced results from previous investigations. Examples of these methodological inconsistencies include severity of heat exposure (duration and temperature), the complexity of the cognitive task(s) completed, previous experience of participants, hydration status, the definition of heat stress (high ambient or $T_{c}$ ), and the design employed to attain an increase in $T_{c}$ (passive or exercise induced). Discussing each of these confounding issues in detail is beyond the scope of this focused review, however, the reader is directed to reviews which have addressed each of these issues at length (Hancock and Vasmatzidis, 2003; Hancock et al., 2007; Gaoua, 2010). When discussing both the mechanistic and observational evidence regarding heat stress induced cognitive alterations, the authors' have drawn upon data from studies using human passive heat stress models (to eliminate any confounding effect of exercise). Relevant recent literature in this area is collated within Table 2, and is drawn upon when making conclusions regarding the true effects of passive heat stress on cognitive function.

It is generally accepted that simple task performance is less vulnerable to heat stress than complex task performance, a viewpoint that has been supported by recent literature reviews (Hancock, 1986; Pilcher et al., 2002; Hancock and Vasmatzidis, 2003; Gaoua, 2010). Complex tasks such as working memory (spatial span test, pattern recognition) were significantly impaired through heat stress $\left[45 \mathrm{~min}\right.$ at $50^{\circ} \mathrm{C}$, $50 \%$ relative humidity (r.h.)], whereas simple attentional tasks (match to sample, choice reaction time, rapid visual information processing) were not affected (Gaoua et al., 2011). Moreover, 
TABLE 2 | The effects of passive heat stress on cognitive function.

\begin{tabular}{|c|c|c|c|c|c|}
\hline Author and date & $\begin{array}{c}\text { Environment } \\
\text { (temperature) }\end{array}$ & Duration & $\begin{array}{l}\text { Cognitive assessment } \\
\text { tool }\end{array}$ & Physiological response & Cognitive alterations \\
\hline Gaoua et al., 2012 & $50^{\circ} \mathrm{C}, 30 \%$ r.h. & $15 \mathrm{~min}$ & $\begin{array}{l}\text { Reaction time and task } \\
\text { planning }\end{array}$ & $\begin{array}{l}\text { Tc not elevated. Tsk elevated } \\
\text { by } \sim 3^{\circ} \mathrm{C} \text {. }\end{array}$ & $\begin{array}{l}\text { Decreased accuracy in task } \\
\text { planning. Subjects took more } \\
\text { time ( } 41 \% \text { increase) to find } \\
\text { correct response. }\end{array}$ \\
\hline Liu et al., 2013 & $50^{\circ} \mathrm{C}, 40 \%$ r.h. & $45 \mathrm{~min}$ & Attention Network Test & $\begin{array}{l}\text { Tc elevated to } 38.5^{\circ} \mathrm{C} \text {. Tsk not } \\
\text { reported. }\end{array}$ & Impaired executive function. \\
\hline Lenzuni et al., 2014 & $53.3-66.9^{\circ} \mathrm{C}$ & $15-20 \min$ & $\begin{array}{l}\text { Driving in a straight line, } \\
\text { and identifying a cue } \\
\text { and reacting correctly }\end{array}$ & $\begin{array}{l}\text { Tc elevated by } \sim 0.3^{\circ} \mathrm{C} \text {. Tsk } \\
\text { not reported. }\end{array}$ & $\begin{array}{l}\text { Impaired cognitive function in } \\
\text { both simple and complex tasks } \\
\sim 50 \%\end{array}$ \\
\hline Berg et al., 2015 & $26^{\circ} \mathrm{C}$ & $30 \mathrm{~min}$ & $\begin{array}{l}\text { Peg transfer and } \\
\text { intracoporeal knot tying }\end{array}$ & None reported & $\begin{array}{l}\text { None despite reduced thermal } \\
\text { comfort }\end{array}$ \\
\hline Watkins et al., 2014 & $30^{\circ} \mathrm{C}, 50 \%$ r.h. & $\begin{array}{l}90 \text { min with } 15 \text { min } \\
\text { normothermic exposure } \\
\text { at half-way }\end{array}$ & $\begin{array}{l}\text { Dual task (tracking + } \\
\text { simple reaction) and } \\
\text { numerical vigilance }\end{array}$ & $\begin{array}{l}\text { Tc elevated by } \sim 0.2^{\circ} \mathrm{C} \text {. Tsk } \\
\text { elevated by } \sim 4^{\circ} \mathrm{C} .\end{array}$ & None \\
\hline Gaoua et al., 2011 & $50^{\circ} \mathrm{C}, 50 \%$ r.h. & $45 \min$ & $\begin{array}{l}\text { Attention and memory } \\
\text { tests }\end{array}$ & $\begin{array}{l}\text { Tc elevated to } 38.6^{\circ} \mathrm{C} \text {. Tsk } \\
\text { elevated to } 39.6^{\circ} \mathrm{C} \text {. }\end{array}$ & $\begin{array}{l}\text { Attention not impaired but } \\
\text { memory impaired }\end{array}$ \\
\hline Racinais et al., 2008 & $50^{\circ} \mathrm{C}, 50 \%$ r.h. & $\begin{array}{l}15 \text { min walk at } 3-5 \mathrm{~km} / \mathrm{h} \text {. } \\
\text { Followed by } 45 \mathrm{~min} \\
\text { passive exposure. }\end{array}$ & $\begin{array}{l}\text { Attention, working and } \\
\text { visual memory }\end{array}$ & $\begin{array}{l}\text { Tc elevated to } 38.8^{\circ} \mathrm{C} \text {. Tsk } \\
\text { elevated to } 39^{\circ} \mathrm{C} \text {. }\end{array}$ & $\begin{array}{l}\text { Attention not impaired but } \\
\text { working and visual memory } \\
\text { impaired }\end{array}$ \\
\hline Sun et al., 2012 & $50^{\circ} \mathrm{C}, 40 \%$ r.h. & $60 \mathrm{~min}$ & Attention Network Test & Tc elevated to $38.4^{\circ} \mathrm{C}$ & Impaired executive function \\
\hline Wijayanto et al., 2013 & $42^{\circ} \mathrm{C}$ & $45 \min$ & Short term memory & Delta Tc elevated by $0.31^{\circ} \mathrm{C}$ & None \\
\hline Simmons et al., 2008 & $45^{\circ} \mathrm{C}, 50 \%$ r.h. & $\begin{array}{l}\text { Until Tc increased by } \\
1^{\circ} \mathrm{C} . \text { (Time unknown) }\end{array}$ & $\begin{array}{l}\text { Reaction time and } \\
\text { numerical vigilance }\end{array}$ & $\begin{array}{l}\text { Tc elevated by } 1^{\circ} \mathrm{C} \text {. Tsk } \\
\text { elevated by } 6^{\circ} \mathrm{C} \text {. }\end{array}$ & $\begin{array}{l}\text { Faster reaction time but } \\
\text { reduced accuracy }\end{array}$ \\
\hline
\end{tabular}

Watkins et al. (2014) recently demonstrated that soccer goal line officials' ability to complete simple tasks (tracking, simple reaction time, and numerical vigilance) does not deteriorate during a $90 \mathrm{~min}$ passive exposure to $30^{\circ} \mathrm{C}, 40 \%$ r.h. However, the authors neglected to assess complex cognitive task performance and the severity of heat stress was unlikely to impose significant stress, especially using a passive model. Previous reviews also suggest that cognitive function is generally unaffected unless the external stimulus is sufficient in intensity and duration to increase $T_{c}$ away from a homeostatic range approximate to $37^{\circ} \mathrm{C}$ (Hancock and Vasmatzidis, 2003). An early study led to this theory (Wilkinson et al., 1964), whereby as $T_{c}$ increased to $38.5^{\circ} \mathrm{C}$ (through passive heating), simple task performance (vigilance) improved but complex task performance (mental addition) was compromised. However, in a later study, it was shown that passively heating individuals up to $39.05^{\circ} \mathrm{C}$ did not affect short or long term memory, verbal logic problems, and numerical subtraction performance (Holland et al., 1985). Therefore, it seems that in a hot environment $T_{c}$ alone may not be a reliable predictor of cognitive performance decline. In support, recent research suggests that an increased skin temperature $\left(T_{s k}\right)$, independent of any rise in $T_{c}$, may be responsible for any heat induced cognitive deteriorations (Gaoua et al., 2012). Participants in the aforementioned study were passively exposed to $50^{\circ} \mathrm{C}, 30 \% \mathrm{r}$.h. for $\sim 15 \mathrm{~min}$, and were required to complete simple (reaction time) and complex (working memory) tasks during the exposure. The results demonstrated that simple task performance was not affected, however complex task performance was significantly impaired. Thus, it appears that $T_{s k}$ (which was significantly increased in the heat by $\sim 3^{\circ} \mathrm{C}$ ) and a reduced thermal comfort ( $\sim 8$ points on a 20 point scale) in the heat, whereby subjects reported more negative feelings (i.e., they felt hotter and less comfortable), were responsible for the reductions in complex task performance, which again were independent of any change in $T_{c}$ (Gaoua et al., 2012). It may therefore be suggested that the subjective state of the individual could be a key factor affecting cognitive function in the heat, as these responses led to alterations in complex task performance independent of variations in $T_{c}$. Indeed, selective head skin cooling (induced by three cooling packs) has been shown to preserve some complex cognitive functions (Gaoua et al., 2011). Therefore, it seems that increasing thermal comfort (rather than mitigating $T_{c}$ increases) may be effective in maintaining complex cognitive function (and consequently safety) in passively experienced thermally stressful environments.

Recent investigations have utilized the attention network test (ANT) and functional magnetic resonance imaging (fMRI) to provide an insight into brain blood flow alterations upon exposure to heat stress, and how these changes affect aspects of the attention network (Jiang et al., 2013; Liu et al., 2013; Sun et al., 2013). The ANT (Macleod et al., 2010) is a tool used to measure the efficiency of three major attention networks;

\section{KEY CONCEPT 1 | Attention Network}

Neuroscientific studies suggest that specific attentional functions are carried out by several interconnected brain networks. The attentional functions and related networks go under different names, but a classification into the three networks of alerting, orienting, and executive control is common. It is now understood that under many circumstances these networks interact and influence each other. 


\section{KEY CONCEPT 2 | Functional Magnetic Resonance Imaging}

This method highlights differences in brain activity by measuring related blood oxygenation levels. It yields information regarding relative differences in brain activity when comparing two or more experimental conditions and thus offers useful insight as to which brain areas are selectively active during certain mental processes.

alerting (simple task; related to maintaining readiness), orienting (simple task; responsible for selecting the region of space or channel to be attended), and executive control (complex task; involved in resolving conflict among possible actions). These three aspects of attention differ from one another in brain activation locations (Petersen and Posner, 2012), hence, the application of fMRI has allowed researchers to accurately and simultaneously quantify how blood flow/activation in these areas vary upon exposure to environmental heat stress and relative to differential (simple or complex) cognitive tasks. In support of previous findings (see Table 2), passive heat exposure ( $1 \mathrm{~h}$ at $50^{\circ} \mathrm{C}, 40 \%$ r.h.) did not alter simple task (alerting and orienting) performance for reaction time or accuracy (Liu et al., 2013). The lack of heat induced cognitive alteration in these tasks appear to be due to increased activation in alternative brain regions i.e., a compensatory effect (see Table 3 ). Conversely, passive hyperthermia had a significant adverse effect on complex cognitive processes involving executive function, with reaction time increasing by $\sim 22 \mathrm{~ms}$. During the executive function task, there was no difference in activation at the anterior cingulate cortex (brain region involved in executive functioning) between the normothermic and hyperthermic groups, but again there appeared to be compensatory activation (Table 3). It is currently unclear why this type of complex task performance is consistently impaired by heat stress (Table 2) given the apparent compensatory activation. Similar results have been found elsewhere (Sun et al., 2012, 2013), however it is currently unknown if these changes were mediated by an increased $T_{s k}$ (not reported) or $T_{c}$ (peak $\sim 38.5^{\circ} \mathrm{C}$ ). A plausible explanation for these behavioral changes is that the increase in plasma serotonin (5hydroxytryptamine; 5-HT) witnessed during passive heat stress (McMorris et al., 2006) inhibits the production of dopamine (DA), a neurotransmitter that appears to play a major role in complex task performance [executive function; (Rektor et al., 2003)]. As stated previously, the precise relationship between $T_{s k}$

TABLE 3 | Summary of activated and depressed brain regions during passive heat stress (Liu et al., 2013).

\begin{tabular}{|c|c|c|c|}
\hline & Alerting network & $\begin{array}{l}\text { Orienting } \\
\text { network }\end{array}$ & Executive network \\
\hline $\begin{array}{l}\text { Increased } \\
\text { activity }\end{array}$ & $\begin{array}{l}\text { Right superior frontal } \\
\text { gyrus }\end{array}$ & Temporal lobe & $\begin{array}{l}\text { Frontal lobe } \\
\text { Superior temporal gyrus } \\
\text { Lingual gyrus }\end{array}$ \\
\hline \multirow[t]{3}{*}{$\begin{array}{l}\text { Depressed } \\
\text { activity }\end{array}$} & $\begin{array}{l}\text { Right middle occipital } \\
\text { gyrus }\end{array}$ & $\begin{array}{l}\text { Frontal Parietal } \\
\text { lobe }\end{array}$ & Post-central gyrus \\
\hline & $\begin{array}{l}\text { Left inferior parietal } \\
\text { lobe }\end{array}$ & Occipital lobe & \\
\hline & Left culmen & & \\
\hline
\end{tabular}

and 5-HT is currently unknown, therefore future work should examine if; (1) 5-HT plays a major role in these heat stress induced cognitive alterations, and (2) if plasma (human) and/or brain (animal models) 5-HT increases in response to an elevated $T_{s k}$ and/or $T_{c}$ differentially. To our knowledge, this relationship is yet to be examined.

The available evidence demonstrates that heat stress related cognitive decline is primarily mediated by a reduction in thermal comfort (Gaoua et al., 2012) and/or changes in regional brain blood flow (Liu et al., 2013; Qian et al., 2013). Although the involvement of 5-HT is not yet well established, evidence has shown that augmenting the bioavailability of the amino acid tyrosine (a precursor for DA synthesis) may preserve cognitive function during thermal stress (Wurtman et al., 1980). In support, it has recently been shown that tyrosine $(6.5 \mathrm{~g})$ ingested $90 \mathrm{~min}$ prior to passive heat stress $\left(90 \mathrm{~min}\right.$ at $45^{\circ} \mathrm{C}, 30 \%$ r.h.) significantly decreased event related potential (P300) latency and contingent negative variation latency compared with a placebo (Kishore et al., 2013). Moreover, there was a significant increase in plasma DA concentrations when participants ingested tyrosine (Kishore et al., 2013), an effect which may be responsible

\section{KEY CONCEPT 3 | Tyrosine}

Tyrosine, a non-essential amino acid synthesized in the liver from phenylalanine, is a precursor for the synthesis of catecholamines. Nutritional supplementation of tyrosine increases its ratio to other large chain amino acids, and can result in a greater cerebral uptake of dopamine and noradrenaline. Evidence suggests that this response helps maintain cognitive function in extreme environmental conditions.

for the improved cognitive function. Conversely, it has been shown that $150 \mathrm{mg} \cdot \mathrm{kg}^{-1}$ tyrosine ingestion prior to exhaustive exercise did not affect cognitive function in a warm environment compared to a placebo (Watson et al., 2012). However, the environmental conditions (i.e., thermal stress) may not have been sufficient in magnitude to increase plasma 5-HT, as to our knowledge, this has not been shown to increase in such a mild environment. Thus, as plasma DA levels were not assessed in the aforementioned study, and tyrosine works by increasing DA concentrations, it is impossible to draw conclusions about the true effects of tyrosine in this work. Although there are very few well controlled studies in this area, the evidence available (Kishore et al., 2013) suggests that ingestion of tyrosine may be an effective strategy to maintain cognitive function during passive heat stress. Finally, as sensory displeasure (decreased thermal comfort elicited through an increased $T_{s k}$ ) may be the primary factor mediating heat stress induced cognitive disturbances (Gaoua et al., 2012), it is reasonable to suggest that improving thermal comfort (through an acute reduction in $T_{s k}$ ) may also combat the negative side effects of heat stress on complex cognitive functioning. However, results to date have not wholly supported this notion. For example, a recent study has shown that ingestion of menthol lozenges had no such effect (Zhang et al., 2014) during simulated firefighting in the heat. However, when applied directly to the skin, menthol has a stimulating action on the peripheral cold receptor TRPM8 (Eccles, 2000), thus, the ingestion of menthol lozenges is likely to be an inferior intervention compared to direct menthol application 
to the skin. It is important to note that the effect of menthol on thermal comfort is dose dependent, whereby concentrations of $<2 \%$ elicit a cool sensation (Cliff and Green, 1994), but concentrations $>2 \%$ may cause irritation and burning sensations (Yosipovitch et al., 1996). Research is needed to determine if topically applied menthol (at concentrations $<2 \%$ ) is effective at improving thermal comfort and consequently maintaining complex cognitive function during heat stress.

\section{Cold Stress}

Cold stress is experienced in occupational (military, fishing trawlers, emergency disaster workers) and athletic (winter sports) settings (Muller et al., 2012). It appears that both moderate and extreme reductions in ambient temperature may have a negative effect on cognitive function (Banderet et al., 1986; Palinkas, 2001). Specifically, cold exposure $\left(-20\right.$ to $\left.10^{\circ} \mathrm{C}\right)$ has led to decrements in memory [complex task (Thomas et al., 1989; Patil et al., 1995)], vigilance [complex task (Flouris et al., 2007)], reaction time [simple task (Teichner, 1958; Ellis, 1982)], and decision making [complex task; see Table 4; (Watkins et al., 2014)]. Such consistent findings across such diverse ambient temperatures may be explained by traditional theories of cold induced cognitive decrement (Teichner, 1958; Enander, 1987; Muller et al., 2012). The distraction theory (Teichner, 1958) explains that exposure to cold conditions provides alternative stimuli to interrupt focus which would otherwise be fixed on the cognitive task at hand (i.e., attention is focused on feeling cold rather than completing the cognitive task provided). This theory is supported by recent findings where temperatures as mild as $10^{\circ} \mathrm{C}$ (Muller et al., 2012) may have provided enough of a sensory challenge to distract participants from a set cognitive task. Regression analysis from a recent study (Watkins et al., 2014) reported a significant relationship between alterations in thermal comfort and cognitive function in the cold.
Exposure to cold conditions alters the concentration of central catecholamines [DA, epinephrine and norepinephrine (Avakian et al., 1984)]. Alterations in levels of central catecholamines (Rauch and Lieberman, 1990) may have a detrimental effect on cognition as brain regions such as the prefrontal cortex are reliant on these neurotransmitters for normal function (Rektor et al., 2003; Friston et al., 2014). There is a plethora of evidence which demonstrates that tyrosine supplementation improves cognitive function during acute cold stress (Shurtleff et al., 1993, 1994; Yeghiayan et al., 2001; Palinkas et al., 2005; Mahoney et al., 2007; O'Brien et al., 2007). Given that tyrosine is a precursor for the synthesis of norepinephrine and DA, these studies support the notion that alterations in catecholamine concentrations may play a role for cold stress induced cognitive impairment. However, further support is needed to clarify if this is the case in humans.

Tyrosine supplementation is likely to improve cognitive function during exposure to cold environmental conditions (as previously described). Similar augmentation of cognitive function was observed following the use of caffeine, although this was during exposure to multiple stressors [cold, intense physical and psychological stress (Lieberman et al., 2002)]. The implementation of multiple stressors makes it difficult to attribute any improvements in cognitive function to caffeine supplementation. However, as caffeine may increase metabolic rate (and potentially increase in $T_{c}$; Poehlman et al., 1985) this may provide a favorable physiological effect when exposed to cold conditions. Adequate clothing for cold, dry environments should aim to block airflow but enable water vapor to dissipate if sweating occurs, i.e., to maintain body heat balance (Holmér, 1988). Cold acclimation or acclimatization is suggested to result in reduced vasoconstriction, increased skin temperature, delayed onset of shivering, dampened release of stress hormones, and reduced thermal discomfort (Mäkinen et al., 2006). Specifically, a reduction in cold stress from acclimation or acclimatization should in theory limit shivering and thermal discomfort and thus

TABLE 4 | The effects of passive cold exposure on cognitive function.

\begin{tabular}{|c|c|c|c|c|c|}
\hline $\begin{array}{l}\text { Author and } \\
\text { date }\end{array}$ & $\begin{array}{l}\text { Environment } \\
\text { (temperature) }\end{array}$ & Duration & Cognitive assessment tool & Physiological response & Cognitive alterations \\
\hline $\begin{array}{l}\text { Shurtleff et al., } \\
1994\end{array}$ & $4^{\circ} \mathrm{C}$ & $30 \mathrm{~min}$ & Match to Sample & $\begin{array}{l}\text { Increased systolic blood } \\
\text { pressure following cold exposure }\end{array}$ & $\begin{array}{l}\text { Cold exposure reduced } \\
\text { matching accuracy }\end{array}$ \\
\hline $\begin{array}{l}\text { Patil et al., } \\
1995\end{array}$ & $\begin{array}{l}2-3^{\circ} \mathrm{C} \text { (Cold Water } \\
\text { Immersion) }\end{array}$ & $3 \mathrm{~min}$ & $\begin{array}{l}\text { Variety of simple and complex } \\
\text { tasks }\end{array}$ & $\begin{array}{l}\text { Increased systolic and diastolic } \\
\text { blood pressure following cold } \\
\text { water immersion }\end{array}$ & $\begin{array}{l}\text { Cold exposure increased } \\
\text { alertness, but worsened } \\
\text { short-term memory }\end{array}$ \\
\hline $\begin{array}{l}\text { Banderet } \\
\text { et al., } 1986\end{array}$ & $\begin{array}{l}\text { Night: }-4 \text { to }-10^{\circ} \mathrm{C} \\
\text { Day: }-23 \text { to }-25^{\circ} \mathrm{C}\end{array}$ & 5 days & $\begin{array}{l}\text { Pattern and number comparison, } \\
\text { grammatical reasoning, coding }\end{array}$ & None reported & $\begin{array}{l}\text { All cognitive tasks impaired aside } \\
\text { from grammatical reasoning }\end{array}$ \\
\hline $\begin{array}{l}\text { Marrao et al., } \\
2005\end{array}$ & $\begin{array}{l}9 \text { day range: }-24 \text { to } \\
4.4^{\circ} \mathrm{C}\end{array}$ & 9 days & $\begin{array}{l}\text { Logical planning, reasoning, } \\
\text { vigilance }\end{array}$ & $\begin{array}{l}\text { No significant thermoregulatory } \\
\text { changes }\end{array}$ & None \\
\hline $\begin{array}{l}\text { Mäkinen et al., } \\
2006\end{array}$ & $10^{\circ} \mathrm{C}$ & 10 days & Cognitive Battery (ANAM-ICE) & $\begin{array}{l}\text { Significant reductions in Tc, Tsk } \\
\text { and finger temperature across } \\
\text { exposure }\end{array}$ & $\begin{array}{l}\text { Cold exposure increased } \\
\text { response time, decreased } \\
\text { accuracy, and efficiency of tasks }\end{array}$ \\
\hline $\begin{array}{l}\text { O'Brien et al., } \\
2007\end{array}$ & $\begin{array}{l}10 \text { or } 15^{\circ} \mathrm{C} \text { (Cold Water } \\
\text { Immersion). } \\
\text { Subsequent cold air } \\
\text { exposure until Tcore } \\
\text { reached } 35.5^{\circ} \mathrm{C} \text {. }\end{array}$ & $\mathrm{N} / \mathrm{A}$ & $\begin{array}{l}\text { Match to Sample, complex } \\
\text { reaction time, logical reasoning, } \\
\text { visual vigilance, addition and } \\
\text { subtraction, repeated acquisition }\end{array}$ & $\begin{array}{l}\text { Cold water immersion reduced } \\
\text { Tc by } 0.3 \text { to } 1^{\circ} \mathrm{C} \text {. Tsk reduced to } \\
\sim 26^{\circ} \mathrm{C} \text {. Finger temperature } \\
\text { reduced to } \sim 15^{\circ} \mathrm{C} \text {. }\end{array}$ & $\begin{array}{l}\text { Cognitive function was not } \\
\text { affected by cold water immersion }\end{array}$ \\
\hline
\end{tabular}

Regard et al., 1989; Racinais et al., 2008; Berg et al., 2015. 
potentially limit the level of distraction and thus may positively influence cognitive function. Despite this, it was demonstrated that 10 days repeated exposure to $10^{\circ} \mathrm{C}$ did not significantly alter cognitive function, including accuracy, efficiency and response time, when compared to control (Mäkinen et al., 2006).

Given the equivocal nature of acclimation/acclimatization and tyrosine supplementation on cold induced cognitive function disturbances, appropriate clothing to maintain thermal comfort is the only robust intervention presently available. Evidently, further interventional work is required to positively influence the cold environment cognition nexus.

\section{HYPOXIA AND COGNITIVE FUNCTION}

Hypoxia is defined as a reduction in alveolar oxygen partial pressure $\left[\mathrm{PaO}_{2}\right.$ (Petrassi et al., 2012)]. Reduced $\mathrm{PaO}_{2}$ availability is experienced at high altitudes $(\sim 1500-7500 \mathrm{~m})$ and has been shown to have detrimental effects on cognitive function in human subjects (Abraini et al., 1998; Adam et al., 2008b; de Aquino Lemos et al., 2012). In accordance with the previous sections, there are a number of confounding variables that must be considered when reviewing the relationship between hypoxia and cognitive function. These include altitude severity, ambient temperature, the addition of exercise, variability in physiological responses, and the differences in barometric pressure (ViruésOrtega et al., 2004). The present section will primarily review studies which assess changes in cognitive function in a laboratory setting, and studies which have used passive hypoxic exposures (normobaric and hypobaric).

It is generally accepted that there is a negative correlation between altitude and cognitive function (Table 5; Li et al., 2000; Pickard, 2002; Rainford and Gradwell, 2006; Merz et al., 2013; Neuhaus and Hinkelbein, 2014; Xu et al., 2014). Increases in reaction time (simple task) have been observed at altitudes exceeding $5000 \mathrm{~m}$, an effect which persisted 75 days after participants returned to sea level following acute altitude exposure (Cavaletti and Tredici, 1993). As individuals ascend to altitude $>5000 \mathrm{~m}$, decrements in all facets of memory (complex tasks) have been observed; including learning (Bouquet et al., 1999), spatial (Nelson, 1982), and working memory (Yan et al., 2011; Champod et al., 2013; Malle et al., 2013). More recently, 90 min exposure to a simulated altitude of $6096 \mathrm{~m}[10 \%$ oxygen $\left(\mathrm{O}_{2}\right)$ ] significantly deteriorated many aspects of cognitive function, including complex attention, executive function, and cognitive flexibility (Turner et al., 2015). In the field, Kramer et al. (1993) demonstrated using a battery of cognitive tests (pattern comparison, code substitution, reaction time, memory) that altitude induced deficits in short term memory and reaction time. The tests took place at Genet Basin, 14,200 ft (4328 m) above sea level, and results were compared with a matched control group who completed the same tests at sea level. Interestingly, the climber's ability to learn new skills was also monitored upon return to sea level, and it was shown to be impaired for up to 2 weeks. These results support the notion that high altitude exposure causes acute and chronic deficits in cognitive function.
An fMRI study conducted at sea level revealed that subjects that had experienced chronic hypobaric hypoxia $(>18$ years; $\sim 2616-4200 \mathrm{~m}$ ) displayed decreased activation in a number of brain regions (various gyri, pyramis of vermis, and thalamus) as well as reduced performance during complex cognitive tasks (working memory) when compared to their sea level counterparts (Yan et al., 2011). Interestingly, another study revealed that those exposed to chronic ( 7 months) moderate hypobaric hypoxia $(2260 \mathrm{~m})$ performed similarly to a group of sea level residents during a battery of complex tasks taken place at sea level (verbal, spatial, long term memory), although impairments in simple task performance were evident [short term memory (Zhang et al., 2011)]. Finally, acute ascents to high altitudes can cause alterations to cerebral architecture (Wilson et al., 2009). The use of fMRI revealed that world-class climbers (sea level residents) acutely exposed to hypobaric hypoxia displayed modifications to cerebral tissue (Paola et al., 2008), in comparison to a sea level control group. Specifically, the climbers displayed a reduction in left angular gyrus volume, a key brain region involved in movement control and planning (Paola et al., 2008).

Traditionally it has been thought that acclimatization to various environmental conditions could be used as an intervention to improve cognitive function. Although this may be true with regard to athletic performance, fMRI has uncovered a number of negative adaptations in those chronically exposed to hypobaric hypoxia [ 2600-6500 m (Paola et al., 2008; Zhang et al., 2010; Yan et al., 2011)]. For example, chronic exposure to hypobaric hypoxia has been shown to reduce the cerebral volume of both gray and white matter [ $>15$ years at altitude (Zhang et al., 2010)]. In highland dwellers, gray matter volume was reduced in the prefrontal cortex, the anterior insular cortex, the anterior cingulate cortex, and the lingual cortex (Zhang et al., 2010), and these changes were still visible 1 year after returning to sea level. Alternatively, the cognitive deficits suffered during chronic high altitude exposure may be due to hyperhomocysteinemia. Elevated circulating levels of homocysteine have been associated with declines in cognitive function in several geriatric population based studies (Wright et al., 2004), and there is a strong correlation between homocysteine in plasma and cognitive impairment during chronic (18 months) hypoxia exposure (Sharma et al., 2014). Interestingly, this study further supports the notion that altitude acclimatization does not induce a favorable adaptation with regards to cognitive function.

\section{KEY CONCEPT 4 | Hyperhomocysteinemia}

Hyperhomocysteinaemia is a condition characterized by an abnormally high level of homocysteine present in the circulation. Interestingly, a recent study found that cognitive impairment (visuo-spatial executive, attention, delayed recall, and procedural memory related cognitive domains) is progressively associated with duration of stay at high altitude and is strongly correlated with elevated homocysteine in plasma.

The mechanisms which explain how acute hypoxia impairs cognitive function are not completely clear, although it is likely an amalgamation of factors which may include neuronal damage (Bjursten et al., 2010), the onset of altitude sickness (Wilson et al., 2009), and fatigue (Virués-Ortega et al., 2004). 
TABLE 5 | The effects of passive hypoxia on cognitive function.

\begin{tabular}{|c|c|c|c|c|c|}
\hline Author and date & $\begin{array}{l}\text { Environment } \\
\text { (altitude) }\end{array}$ & Duration & Cognitive assessment tool & Physiological response & Cognitive alterations \\
\hline $\begin{array}{l}\text { Adam et al., } \\
2008 b\end{array}$ & $4300 \mathrm{~m}$ & 5 days & Mental addition & None reported & $\begin{array}{l}\text { Cognitive performance was better } \\
\text { at sea level than altitude }\end{array}$ \\
\hline $\begin{array}{l}\text { de Aquino Lemos } \\
\text { et al., } 2012\end{array}$ & $4500 \mathrm{~m}$ & $24 \mathrm{~h}$ & $\begin{array}{l}\text { Vigor, attention, visual and } \\
\text { working memory, concentration, } \\
\text { executive functions, inhibitory } \\
\text { control, and speed of mental } \\
\text { processing }\end{array}$ & $\begin{array}{l}\text { Decreased sleep time and } \\
\text { rapid eye movement sleep }\end{array}$ & $\begin{array}{l}\text { Decreased performance in all } \\
\text { facets of cognitive function } \\
\text { measured }\end{array}$ \\
\hline Merz et al., 2013 & $\begin{array}{l}4497,5533,6265 \\
6865,7546 \mathrm{~m}\end{array}$ & N/A & $\begin{array}{l}\text { Saccadic Eye Movement, } \\
\text { Neuropsychological Testing }\end{array}$ & $\begin{array}{l}\text { Significant reduction in } \\
\mathrm{SaO}_{2} \text { as ascent increases }\end{array}$ & $\begin{array}{l}\text { Neither parameters effect by } \\
\text { altitude exposure }\end{array}$ \\
\hline $\begin{array}{l}\text { Kourtidou- } \\
\text { Papadeli et al., } \\
2008\end{array}$ & $8000 \mathrm{ft}$ & $16 \min$ & Multi attribute task batter (MATB) & None reported & $\begin{array}{l}\text { Increase in errors and a decrease } \\
\text { in tracking performance }\end{array}$ \\
\hline $\begin{array}{l}\text { Pavlicek et al., } \\
2005\end{array}$ & $\begin{array}{l}3 \text { profiles: } \\
450-1500-3000(1) ; \\
450-1500-4500(2) ; \\
450-650-650 \text { (control) }\end{array}$ & $\begin{array}{l}30 \text { min at } \\
\text { each } \\
\text { simulated } \\
\text { altitude }\end{array}$ & $\begin{array}{l}\text { Word fluency, three word } \\
\text { association task. Tachistoscopic } \\
\text { lexical decision task }\end{array}$ & None reported & $\begin{array}{l}\text { No change in performance } \\
\text { between groups. }\end{array}$ \\
\hline Shukitt et al., 1988 & $\begin{array}{l}\text { Exposure to: } 21,17 \\
21,13 \text {, and } 21 \% \\
\text { oxygen }\end{array}$ & $\begin{array}{l}3 \text { days at } \\
\text { each altitude }\end{array}$ & $\begin{array}{l}\text { Addition, coding, computer } \\
\text { interaction, map/compass, } \\
\text { number comparison, pattern } \\
\text { comparison, pattern recognition }\end{array}$ & $\begin{array}{l}\text { Significant reduction in } \\
\mathrm{SaO}_{2} \text { at } 13 \% \text { only }\end{array}$ & $\begin{array}{l}\text { Cognition and mood were only } \\
\text { effected on the first day at } 13 \%\end{array}$ \\
\hline Tripathi et al., 2005 & $10,500 \mathrm{ft}$ & 6 days & $\begin{array}{l}\text { Working Memory and Vigilance } \\
\text { Tasks }\end{array}$ & $\begin{array}{l}\text { Symptoms of acute } \\
\text { altitude sickness }\end{array}$ & $\begin{array}{l}\text { No differences in cognitive } \\
\text { performance across days }\end{array}$ \\
\hline Yan et al., 2011 & $\begin{array}{l}\text { High landers: } \\
\text { 2616-4200 m; } \\
\text { lowlanders <400 m }\end{array}$ & $\begin{array}{l}\text { High landers } \\
\text { ( } \geq 18 \text { years } \\
\text { exposure). }\end{array}$ & Verbal working memory & $\begin{array}{l}\text { High landers had } \\
\text { decreased activation in } \\
\text { numerous brain regions } \\
\text { compared to low landers }\end{array}$ & $\begin{array}{l}\text { Longer reaction time and } \\
\text { decreased accuracy in } \\
\text { highlanders }\end{array}$ \\
\hline Li et al., 2000 & $\begin{array}{l}2800,3600, \text { and } \\
4400 \mathrm{~m}\end{array}$ & $\begin{array}{l}60 \mathrm{~min} \text { at } \\
\text { each altitude }\end{array}$ & $\begin{array}{l}\text { Simple reaction time and four } \\
\text { choice reaction time. }\end{array}$ & None reported & $\begin{array}{l}\text { Four choice reaction time } \\
\text { performance decreases at } 3600 \\
\text { and } 4400 \mathrm{~m}\end{array}$ \\
\hline Abraini et al., 1998 & $\begin{array}{l}\text { Ascent to } 8848 \mathrm{~m} \text { (Mt. } \\
\text { Everest simulation) }\end{array}$ & 31 days & $\begin{array}{l}\text { Visual reaction time, psychomotor } \\
\text { ability and number ordination }\end{array}$ & $\begin{array}{l}\text { Significant reduction in } \\
\mathrm{SaO}_{2} \text { as a function of } \\
\text { elevation }\end{array}$ & $\begin{array}{l}\text { Cognitive decrements } \\
\text { at } \geq 8000 \mathrm{~m} \text { and decrements up } \\
\text { to } 3 \text { days after return to sea level }\end{array}$ \\
\hline Hewett et al., 2009 & $\begin{array}{l}\text { Sea level, 8000, } \\
\text { 10,000, 12,000, } \\
14,000 \mathrm{ft}\end{array}$ & $\begin{array}{l}45 \mathrm{~min} \text { at } \\
\text { each altitude }\end{array}$ & $\begin{array}{l}\text { Cognitive Battery } \\
\text { (Cogscreen-HE) }\end{array}$ & $\begin{array}{l}\text { Significant reduction in } \\
\mathrm{SaO}_{2} \text { as a function of } \\
\text { elevation }\end{array}$ & $\begin{array}{l}\text { No differences in cognitive } \\
\text { performance across altitudes }\end{array}$ \\
\hline Gao et al., 2014 & $\begin{array}{l}\text { Lived at } 4500 \mathrm{~m} \text { for } 1-5 \\
\text { years compared to a } \\
\text { sea level control }\end{array}$ & $\mathrm{N} / \mathrm{A}$ & $\begin{array}{l}\text { Cognitive Battery (WHO } \\
\text { neurobehavioral core test battery) } \\
\text { and Raven standard progressive } \\
\text { matrices }\end{array}$ & $\begin{array}{l}\text { Highlanders exhibited a } \\
\text { significant reduction in } \\
\text { basal } \mathrm{SaO}_{2} \text { and } \mathrm{BDNF} \text {, } \\
\text { and an increased serum } \\
\mathrm{S} 100 \mathrm{~B} \text { compared to sea } \\
\text { level controls }\end{array}$ & $\begin{array}{l}\text { Highlanders exhibited a poorer } \\
\text { cognitive function across a range } \\
\text { of simple and complex tasks. } \\
\text { Mood state was also adversely } \\
\text { affected }\end{array}$ \\
\hline Nelson, 1982 & $\begin{array}{l}\text { Sea level, 3810; } \\
5000 \mathrm{~m} \text {. }\end{array}$ & $\begin{array}{l}35 \text { day } \\
\text { expedition }\end{array}$ & $\begin{array}{l}\text { Bender visual motor Gestalt test } \\
\text { and Porteus maze test }\end{array}$ & None reported & $\begin{array}{l}\text { Marked deterioration in cognitive } \\
\text { functioning at } 5000 \mathrm{~m} \text {. Mood } \\
\text { state was also severly affected }\end{array}$ \\
\hline $\begin{array}{l}\text { Kobrick and } \\
\text { Appleton, } 1971\end{array}$ & $15,000 \mathrm{ft}$ & $48 \mathrm{~h}$ & $\begin{array}{l}\text { Near and far visual acuity, } \\
\text { steropsis, binocular depth } \\
\text { perception, critical flicker fusion, } \\
\text { dark adaptation, response time to } \\
\text { peripheral signals }\end{array}$ & None reported & $\begin{array}{l}\text { Decrements observed in all visual } \\
\text { tasks which peaked after } 60 \text { min } \\
\text { of exposure. Task performance } \\
\text { gradually recovered throughout } \\
\text { the exposure. }\end{array}$ \\
\hline $\begin{array}{l}\text { Regard et al., } \\
1989\end{array}$ & $\begin{array}{l}\text { Climbers had } \\
\text { previously reached } \\
8500 \text { m without } \\
\text { supplementary oxygen }\end{array}$ & $\mathrm{N} / \mathrm{A}$ & $\begin{array}{l}\text { Concentration, short term } \\
\text { memory, ability to shift concepts }\end{array}$ & $\begin{array}{l}\text { Malfunctioning of the } \\
\text { bifronto-temporo-limbic } \\
\text { structures }\end{array}$ & $\begin{array}{l}\text { Majority of climbers sampled } \\
\text { suffered impaired concentration, } \\
\text { memory, and ability to control } \\
\text { errors after returning to sea level }\end{array}$ \\
\hline $\begin{array}{l}\text { Kramer et al., } \\
1993\end{array}$ & $\begin{array}{l}14,200 \mathrm{ft} \text { (5-9 day } \\
\text { ascent) }\end{array}$ & 18-26 days & $\begin{array}{l}\text { Pattern comparison, choice } \\
\text { reaction time, memory, tapping, } \\
\text { code substitution }\end{array}$ & $\begin{array}{l}\text { Presence of moderate } \\
\text { acute mountain sickness } \\
\text { in all subjects }\end{array}$ & $\begin{array}{l}\text { Climbers showed deficits in } \\
\text { learning and retention in memory } \\
\text { tasks and slower reaction time. }\end{array}$ \\
\hline
\end{tabular}


Off-setting this response may be achievable through the administration of Dehydroepiandrosterone (DHEA), which has been reported to curtail neuronal damage [measured in vivo via plasma S100 $\beta$ quantification (Bjursten et al., 2010; Winter et al., 2014)] through enhancing the production of brain derived neurotrophic factor (Rahmani et al., 2013; Sakr et al., 2014). Furthermore, DHEA administration has been shown to improve complex cognitive functioning and increase levels of central catecholamines in the rat (Sakr et al., 2014). This is significant as the maintenance of dopamine is necessary for executive functioning (Rektor et al., 2003). Future research may consider the implementation of DHEA for its neuroprotective effects, particularly in those individuals exposed to high altitudes on a regular basis or for prolonged periods. It is important to stress that DHEA is on the World AntiDoping Agency (WADA) banned substances list and thus is prohibited during athletic competition (although this would not preclude its acute short-term use in recreational or occupational settings). Other supplementary aids, which are not banned by WADA, such as tyrosine, have been used successfully to offset hypoxia-induced symptoms, adverse moods, and cognitive decrement (Banderet and Lieberman, 1989). Additionally, creatine supplementation significantly maintained cognitive function in a variety of tasks compared with placebo supplementation during severe hypoxia [90 min at $6096 \mathrm{~m}$ (Turner et al., 2015)]. Supplementary $\mathrm{O}_{2}$ appears to be a logical aid which may offset the negative side effects of hypobaric hypoxia on cognitive function, although a distinct lack of literature exists on this topic. Interestingly, altitude induced reductions in endogenous $\mathrm{O}_{2}$ saturation have not been significantly correlated with cognitive decrement, suggesting inter and intra individual variation regarding the cognition hypoxia nexus (Gao et al., 2014). Further research is required to determine if these ergogenic aids improve cognitive function at high altitude.

\section{FUTURE RESEARCH DIRECTIONS}

Further research is required to reach a more definitive conclusion regarding the effects of passive exposure to extreme environments on cognitive function in humans, and to expand the knowledge and understanding of the potential intervention techniques that can be employed. These advancements are necessary to improve cognitive function and safety during exposure to such environments in a variety of contexts.

As stated, ANT and fMRI have provided an insight into brain blood flow alterations and how the attention network is affected by changes in environmental conditions (Liu et al., 2013; Sun et al., 2013). Such an understanding has been disproportionally advanced in the heat in comparison to cold and hypoxic environments, with intuitive and novel use of ANT alongside fMRI (Jiang et al., 2013; Liu et al., 2013; Sun et al., 2013). Such approaches are required for the remaining environmental extremes. The use of biochemical measures (particularly catecholamines) will increase mechanistic cause and effect evidence relative to the above outlined paradigms, and may aid the development of additional intervention techniques to reduce environmentally mediated cognitive decrements.

There also appears to be a lack of reliability data in the majority of studies utilized within this review. Reliability statistics, including the change in mean, coefficient of variation, intraclass correlation coefficient, and typical error for these cognitive tests (and other experimental procedures) should be overtly reported, as to ensure that the true experimental effects can be correctly disseminated, and to demonstrate the reproducibility of the cognitive tests used. There also appears to be heterogeneity among dependent measures (i.e., cognitive tests) used between studies, making them difficult to compare and thus draw meaningful conclusions. It is recommended that future researchers utilize the ANT in such studies, as this test is simple to implement, and can directly measure the efficiency of the three major attention networks (alerting, orienting, and executive function). Moreover, rigorous familiarization for the cognitive tests (and other experimental procedures) utilized will reduce learning effects which were likely evident in at least some of the previous work outlined within this review; increasing the reliability that the change in cognitive function is caused by environmental exposure and not poor experimental design. For example, experienced workers appear to be less vulnerable to the effects of heat stress than inexperienced workers because of task familiarity (Hancock, 1982). Thus, added experience of the task allows it to become more autonomous and "attention free" (Nunneley et al., 1979). This presents a major confounding factor in previous studies, which is why researchers should implement a minimum of one familiarization session before experimental trials are conducted. The presence of a learning effect can be ruled out when two or more familiarization tests are shown to be highly reliable [normally via intraclass correlations and coefficient of variation analysis (McGawley and Bishop, 2006)]. Furthermore, the proposed interventions could likely induce psychosomatic (i.e., you consume an ice based drink and you believe your body temperature will reduce, whether such a reduction actually occurs or not) and/or bona fide physiological responses (i.e., exogenous oxygenation administration increasing various tissue oxygenation indexes whilst within a hypoxic environment), future research should explore these subtleties (as they are currently not clear) to optimize interventional techniques and provide further mechanistic evidence relative to the content of this Focused Review.

If adhered to, these guidelines could lead to greater knowledge and understanding of the cognitive decrement that often occurs during passive exposure to extreme environments. In turn, this may lead to the development of further interventional techniques, and thus ultimately enable practitioners to reduce the decline in cognitive function during extreme environmental exposure. These outcomes could prove life-saving when applied to many occupational settings.

\section{CONCLUSION}

This review has highlighted the detrimental effects of passive exposure to environmental extremes of heat, cold, and hypoxia 
on cognitive function in simple and complex tasks. A decline in cognitive function can be attributed to a number of mechanisms, dependent on the environment to which the individual is exposed. It should be noted that such declines, across all the environmental conditions, will have some aspect of inter and intra-individual variation.

Alterations in blood flow and sensory displeasure (Gaoua, 2010; Gaoua et al., 2012; Jiang et al., 2013; Sun et al., 2013), hyperhomocysteinemia and potential neuronal damage (Rothermundt et al., 2003; Bjursten et al., 2010; Koh and Lee, 2014; Sharma et al., 2014), and a decrease in catecholamine availability (Shurtleff et al., 1994; Starcke and Brand, 2012) combined with psychological factors (Teichner, 1958; Enander, 1987), appear to be responsible for reductions in cognitive function during hot, hypoxic, and cold exposure, respectively. Although mechanisms detailed within this review have outlined how environmentally mediated changes in cognitive function may occur, there is still a need to unequivocally determine mechanistic cause and effect data to understand the

\section{REFERENCES}

Abraini, J. H., Bouquet, C., Joulia, F., Nicolas, M., and Kriem, B. (1998). Cognitive performance during a simulated climb of Mount Everest: implications for brain function and central adaptive processes under chronic hypoxic stress. Pflügers Archiv. 436, 553-559. doi: 10.1007/s004240050671

Adam, G. E., Carter, R. III, Cheuvront, S. N., Merullo, D. J., Castellani, J. W., Lieberman, H. R., et al. (2008a). Hydration effects on cognitive performance during military tasks in temperate and cold environments. Physiol. Behav. 93, 748-756. doi: 10.1016/j.physbeh.2007.11.028

Adam, G. E., Fulco, C. S., and Muza, S. R. (2008b). Multi-Task Performance at Sea-Level and High Altitude. Natick, MA: DTIC Document.

Ando, S., Hatamoto, Y., Sudo, M., Kiyonaga, A., Tanaka, H., and Higaki, Y. (2013). The effects of exercise under hypoxia on cognitive function. PLOS ONE 8:e63630. doi: 10.1371/journal.pone.0063630

Arbury, S., Jacklitsch, B., Farquah, O., Hodgson, M., Lamson, G., Martin, H., et al. (2014). Heat illness and death among workers - United States, 2012-2013. MMWR Morb. Mortal. Wkly. Rep. 63, 661-665.

Armstrong, L. E., Johnson, E. C., Casa, D. J., Ganio, M. S., McDermott, B. P., Yamamoto, L. M., et al. (2010). The American football uniform: uncompensable heat stress and hyperthermic exhaustion. J. Athl. Train. 45, 117-127. doi: 10.4085/1062-6050-45.2.117

Avakian, E. V., Horvath, S. M., and Colburn, R. W. (1984). Influence of age and cold stress on plasma catecholamine levels in rats. J. Auton. Nerv. Syst. 10, 127-133. doi: 10.1016/0165-1838(84)90051-1

Baker, L. (2013). Effects Of dietary constituents on cognitive and motor skill performance in sports. Sports Sci. 26, 1-6. doi: 10.1111/nure.12157

Balakrishnan, K., Ramalingham, A., Dasu, V., Stephen, J. C., Sivaperumal, M. R., Kumarasamy, D., et al. (2010). Case studies on heat stress related perceptions in different industrial sectors in southern India. Glob. Health Action 3, 1-11. doi: 10.3402/gha.v3i0.5635

Bandelow, S., Maughan, R., Shirreffs, S., Ozgünen, K., Kurdak, S., Ersöz, G., et al. (2010). The effects of exercise, heat, cooling and rehydration strategies on cognitive function in football players. Scand. J. Med. Sci. Sports 20, 148-160. doi: 10.1111/j.1600-0838.2010.01220.x

Banderet, L. E., and Lieberman, H. R. (1989). Treatment with tyrosine, a neurotransmitter precursor, reduces environmental stress in humans. Brain Res. Bull. 22, 759-762. doi: 10.1016/0361-9230(89)90096-8

Banderet, L. E., MacDougall, D., Roberts, D., Tappan, D., and Jacey, M. (1986). Effects of Hypohydration or Cold Exposure and Restricted Fluid Intake Upon Cognitive Performance. Natick, MA: DTIC Document.

Berg, R. J., Inaba, K., Sullivan, M., Okoye, O., Siboni, S., Minneti, M., et al. (2015). The impact of heat stress on operative performance and cognitive psycho-physiological mechanisms underpinning these cognitive changes during exposure to such environments.

A variety of interventional techniques can be implemented to potentially combat the negative effects of exposure across the aforementioned paradigms. The use of cooling interventions (Nunneley et al., 1982; Bandelow et al., 2010; Lee et al., 2014) in the heat, clothing and exercise (Doubt, 1991; Gavin, 2003) in the cold, and nutritional interventions (Banderet and Lieberman, 1989; Lieberman et al., 2002; Baker, 2013; Meeusen, 2014; Coull et al., 2015) across all three extreme environments are supported with evidence suggesting that they are often successful at maintaining cognitive function. Further well controlled research should also investigate if tyrosine supplementation is effective in maintaining cognitive function during exposure to heat, hypoxia, or cold environments. Future studies should focus on implementing empirically informed techniques, and should aim to discover additional methods by which optimal cognitive function can be maintained in extreme environments, in order to avoid detrimental outcomes.

function during simulated laparoscopic operative tasks. Surgery 157, 87-95. doi: 10.1016/j.surg.2014.06.012

Bjursten, H., Ederoth, P., Sigurdsson, E., Gottfredsson, M., Syk, I., Einarsson, O., et al. (2010). S100B profiles and cognitive function at high altitude. High Alt. Med. Biol. 11, 31-38. doi: 10.1089/ham.2009.1041

Bouquet, C. A., Gardette, B., Gortan, C., and Abraini, J. H. (1999). Psychomotor skills learning under chronic hypoxia. Neuroreport 10, 3093-3099. doi: 10.1097/00001756-199909290-00040

Bradley, K., and Higenbottam, C. (2003). "Cognitive performance: effect of druginduced dehydration," in RTO-MP-HFM-086 - Maintaining Hydration: Issues, Guidelines, and Delivery (Boston, MA: RTO Specialists Meeting).

Cavaletti, G., and Tredici, G. (1993). Long-lasting neuropsychological changes after a single high altitude climb. Acta Neurol. Scand. 87, 103-105. doi: 10.1111/j.1600-0404.1993.tb04085.x

Champod, A. S., Eskes, G. A., Foster, G. E., Hanly, P. J., Pialoux, V., Beaudin, A. E., et al. (2013). Effects of acute intermittent hypoxia on working memory in young healthy adults. Am. J. Respir. Crit. Care Med. 187, 1148-1150. doi: 10.1164/rccm.201209-1742LE

Cheung, S. S., McLellan, T. M., and Tenaglia, S. (2000). The thermophysiology of uncompensable heat stress. Physiological manipulations and individual characteristics. Sports Med. 29, 329-359. doi: 10.2165/00007256-20002905000004

Cliff, M. A., and Green, B. G. (1994). Sensory irritation and coolness produced by menthol: evidence for selective desensitization of irritation. Physiol. Behav. 56, 1021-1029. doi: 10.1016/0031-9384(94)90338-7

Coull, N. A., Watkins, S. L., Aldous, J. W., Warren, L. K., Chrismas, B. C., Dascombe, B., et al. (2015). Effect of tyrosine ingestion on cognitive and physical performance utilising an intermittent soccer performance test (iSPT) in a warm environment. Eur. J. Appl. Physiol. 115, 373-386. doi: 10.1007/s00421-014-3022-7

de Aquino Lemos, V., Antunes, H. K. M., dos Santos, R. V. T., Lira, F. S., Tufik, S., and de Mello, M. T. (2012). High altitude exposure impairs sleep patterns, mood, and cognitive functions. Psychophysiology 49, 1298-1306. doi: 10.1111/j.1469-8986.2012.01411.x

Doubt, T. J. (1991). Physiology of exercise in the cold. Sports Med. 11, 367-381. doi: 10.2165/00007256-199111060-00003

Eccles, R. (2000). Role of cold receptors and menthol in thirst, the drive to breathe and arousal. Appetite 34, 29-35. doi: 10.1006/appe.1999.0291

Ellis, H. D. (1982). The effects of cold on the performance of serial choice reaction time and various discrete tasks. Hum. Factors 24, 589-598.

Enander, A. (1987). Effects of moderate cold on performance of psychomotor and cognitive tasks. Ergonomics 30, 1431-1445. doi: 10.1080/001401387089 66037 
Flouris, A. D., Westwood, D. A., and Cheung, S. S. (2007). Thermal balance effects on vigilance during 2-hour exposures to -20 degrees C. Aviat. Space Environ. Med. 78, 673-679.

Friston, K., Schwartenbeck, P., FitzGerald, T., Moutoussis, M., Behrens, T., and Dolan, R. J. (2014). The anatomy of choice: dopamine and decision-making. Philos. Trans. R. Soc. Lond. B Biol. Sci. 369:20130481. doi: 10.1098/rstb. 2013.0481

Gao, Y. X., Li, P., Jiang, C. H., Liu, C., Chen, Y., Chen, L., et al. (2014). Psychological and cognitive impairment of long-term migrators to high altitudes and the relationship to physiological and biochemical changes. Eur. J. Neurol. 22, 1363-1369. doi: 10.1111/ene.12507

Gaoua, N. (2010). Cognitive function in hot environments: a question of methodology. Scand. J. Med. Sci. Sports 20, 60-70. doi: 10.1111/j.16000838.2010.01210.x

Gaoua, N., Grantham, J., Racinais, S., and El Massioui, F. (2012). Sensory displeasure reduces complex cognitive performance in the heat. J. Environ. Psychol. 32, 158-163. doi: 10.1016/j.jenvp.2012.01.002

Gaoua, N., Racinais, S., Grantham, J., and El Massioui, F. (2011). Alterations in cognitive performance during passive hyperthermia are task dependent. Int. J. Hyperthermia 27, 1-9. doi: 10.3109/02656736.2010. 516305

Gavin, T. P. (2003). Clothing and thermoregulation during exercise. Sports Med. 33, 941-947. doi: 10.2165/00007256-200333130-00001

Gopinathan, P. M., Pichan, G., and Sharma, V. M. (1988). Role of dehydration in heat stress-induced variations in mental performance. Arch. Environ. Health 43, 15-17. doi: 10.1080/00039896.1988.9934367

Hancock, P. A. (1982). Task categorization and the limits of human-performance in extreme heat. Aviat. Space Environ. Med. 53, 778-784.

Hancock, P. A. (1986). Sustained attention under thermal-stress. Psychol. Bull. 99, 263-281. doi: 10.1037/0033-2909.99.2.263

Hancock, P. A., Ross, J. M., and Szalma, J. L. (2007). A meta-analysis of performance response under thermal stressors. Hum. Factors 49, 851-877. doi: 10.1518/001872007X230226

Hancock, P. A., and Vasmatzidis, I. (2003). Effects of heat stress on cognitive performance: the current state of knowledge. Int. J. Hyperthermia 19, 355-372. doi: 10.1080/0265673021000054630

Hewett, K. J., Curry, I. P., Rath, E., and Collins, S. M. (2009). Subtle Cognitive Effects of Moderate Hypoxia. Natick, MA: DTIC Document.

Hocking, C., Silberstein, R. B., Lau, W. M., Stough, C., and Roberts, W. (2001). Evaluation of cognitive performance in the heat by functional brian imaging and psycometric testing. Comp. Biochem. Physiol. Part A Mol. Integr. Physiol. 128, 719-734. doi: 10.1016/S1095-6433(01)00278-1

Holland, R. L., Sayers, J. A., Keatinge, W. R., Davis, H. M., and Peswani, R. (1985). Effects of raised body temperature on reasoning, memory, and mood. J. Appl. Physiol. 59, 1823-1827.

Holmér, I. (1988). Assessment of cold stress in terms of required clothing insulation-IREQ. Int. J. Ind. Ergon. 3, 159-166. doi: 10.1016/01698141(88)90017-0

Jiang, Q., Yang, X., Liu, K., Li, B., Li, L., Li, M., et al. (2013). Hyperthermia impaired human visual short-term memory: an fMRI study. Int. J. Hyperthermia 29, 219-224. doi: 10.3109/02656736.2013.786141

Kishore, K., Ray, K., Anand, J. P., Thakur, L., Kumar, S., and Panjwani, U. (2013). Tyrosine ameliorates heat induced delay in event related potential P300 and contingent negative variation. Brain Cogn. 83, 324-329. doi: 10.1016/j.bandc.2013.09.005

Kobrick, J. L., and Appleton, B. (1971). Effects of extended hypoxia on visual performance and retinal vascular state. J. Appl. Physiol. 31, 357-362.

Koh, S. X. T., and Lee, J. K. W. (2014). S100B as a marker for brain damage and blood-brain barrier disruption following exercise. Sports Med. 44, 369-385. doi: 10.1007/s40279-013-0119-9

Kourtidou-Papadeli, C., Papadelis, C., Koutsonikolas, D., Boutzioukas, S., Styliadis, C., and Guiba-Tziampiri, O. (2008). High altitude cognitive performance and COPD interaction. Hippokratia 12, 84-90.

Kramer, A. F., Coyne, J. T., and Strayer, D. L. (1993). Cognitive function at high altitude. Hum. Factors 35, 329-344.

Lamport, D. J., Saunders, C., Butler, L. T., and Spencer, J. P. E. (2014). Fruits, vegetables, $100 \%$ juices, and cognitive function. Nutr. Rev. 72, 774-789. doi: $10.1111 /$ nure. 12149
Lee, J. K., Koh, A. C., Koh, S. X., Liu, G. J., Nio, A. Q., and Fan, P. W. (2014). Neck cooling and cognitive performance following exercise-induced hyperthermia. Eur. J. Appl. Physiol. 114, 375-384. doi: 10.1007/s00421-013-2774-9

Lenzuni, P., Capone, P., Freda, D., and Del Gaudio, M. (2014). Is driving in a hot vehicle safe? Int. J. Hyperthermia 30, 250-257. doi: 10.3109/02656736.2014. 922222

Lezak, M. D. (2004). Neuropsychological Assessment. New York, NY: Oxford University Press.

Li, X. Y., Wu, X. Y., Fu, C., Shen, X. F., Yang, C. B., and Wu, Y. H. (2000). Effects of acute exposure to mild or moderate hypoxia on human psychomotor performance and visual-reaction time. Space Med. Med. Eng. (Beijing) 13, 235-239. doi: 10.1016/S0219-4279(00)00018-1

Lieberman, H. R., Tharion, W. J., Shukitt-Hale, B., Speckman, K. L., and Tulley, R. (2002). Effects of caffeine, sleep loss, and stress on cognitive performance and mood during U.S. Navy SEAL training. Psychopharmacology (Berl) 164, 250-261. doi: 10.1007/s00213-002-1217-9

Liu, K., Sun, G., Li, B., Jiang, Q., Yang, X., Li, M., et al. (2013). The impact of passive hyperthermia on human attention networks: an fMRI study. Behav. Brain Res. 243, 220-230. doi: 10.1016/j.bbr.2013.01.013

Macleod, J. W., Lawrence, M. A., McConnell, M. M., Eskes, G. A., Klein, R. M., and Shore, D. I. (2010). Appraising the ANT: psychometric and theoretical considerations of the attention network test. Neuropsychology 24, 637. doi: $10.1037 / \mathrm{a} 0019803$

Mahoney, C. R., Castellani, J., Kramer, F. M., Young, A., and Lieberman, H. R. (2007). Tyrosine supplementation mitigates working memory decrements during cold exposure. Physiol. Behav. 92, 575-582. doi: 10.1016/j.physbeh.2007.05.003

Mäkinen, T. M., Palinkas, L. A., Reeves, D. L., Pääkkönen, T., Rintamäki, H., Leppäluoto, J., et al. (2006). Effect of repeated exposures to cold on cognitive performance in humans. Physiol. Behav. 87, 166-176. doi: 10.1016/j.physbeh.2005.09.015

Malle, C., Quinette, P., Laisney, M., Bourrilhon, C., Boissin, J., Desgranges, B., et al. (2013). Working memory impairment in pilots exposed to acute hypobaric hypoxia. Aviat. Space Environ. Med. 84, 773-779. doi: 10.3357/ASEM.3482.2013

Marrao, C., Tikuisis, P., Keefe, A. A., Gil, V., and Giesbrecht, G. G. (2005). Physical and cognitive performance during long-term cold weather operations. Aviat. Space Environ. Med. 76, 744-752.

McGawley, K., and Bishop, D. (2006). Reliability of a 5 x 6-s maximal cycling repeated-sprint test in trained female team-sport athletes. Eur. J. Appl. Physiol. 98, 383-393. doi: 10.1007/s00421-006-0284-8

McMorris, T., Swain, J., Smith, M., Corbett, J., Delves, S., Sale, C., et al. (2006). Heat stress, plasma concentrations of adrenaline, noradrenaline, 5hydroxytryptamine and cortisol, mood state and cognitive performance. Int. J. Psychophysiol. 61, 204-215. doi: 10.1016/j.ijpsycho.2005.10.002

Meeusen, R. (2014). Exercise, nutrition and the brain. Sports Med. 44(Suppl. 1), S47-S56. doi: 10.1007/s40279-014-0150-5

Merz, T. M., Bosch, M. M., Barthelmes, D., Pichler, J., Hefti, U., Schmitt, K.-U., et al. (2013). Cognitive performance in high-altitude climbers: a comparative study of saccadic eye movements and neuropsychological tests. Eur. J. Appl. Physiol. 113, 2025-2037. doi: 10.1007/s00421-013-2635-6

Morley, J., Beauchamp, G., Suyama, J., Guyette, F. X., Reis, S. E., Callaway, C. W., et al. (2012). Cognitive function following treadmill exercise in thermal protective clothing. Eur. J. Appl. Physiol. 112, 1733-1740. doi: 10.1007/s00421011-2144-4

Muller, M. D., Gunstad, J., Alosco, M. L., Miller, L. A., Updegraff, J., Spitznagel, M. B., et al. (2012). Acute cold exposure and cognitive function: evidence for sustained impairment. Ergonomics 55, 792-798. doi: 10.1080/00140139.2012.665497

Nelson, M. (1982). Psychological testing at high altitudes. Aviat. Space Environ. Med. 53, 122-126.

Neuhaus, C., and Hinkelbein, J. (2014). Cognitive responses to hypobaric hypoxia: implications for aviation training. Psychol. Res. Behav. Manag. 7, 297-302. doi: 10.2147/PRBM.S51844

Nunneley, S. A., Dowd, P. J., Myhre, L. G., Stribley, R. F., and McNee, R. C. (1979). Tracking-task performance during heat stress simulating cockpit conditions in high-performance aircraft. Ergonomics 22, 549-555. doi: $10.1080 / 00140137908924639$ 
Nunneley, S. A., Reader, D. C., and Maldonado, R. J. (1982). Head-temperature effects on physiology, comfort, and performance during hyperthermia. Aviat. Space Environ. Med. 53, 623-628.

O'Brien, C., Mahoney, C., Tharion, W. J., Sils, I. V., and Castellani, J. W. (2007). Dietary tyrosine benefits cognitive and psychomotor performance during body cooling. Physiol. Behav. 90, 301-307. doi: 10.1016/j.physbeh.2006.09.027

Palinkas, L. A. (2001). Mental and cognitive performance in the cold. Int. J. Circumpolar Health 60, 430-439.

Palinkas, L. A., Mäkinen, T. M., Pääkkönen, T., Rintamäki, H., Leppäluoto, J., and Hassi, J. (2005). Influence of seasonally adjusted exposure to cold and darkness on cognitive performance in circumpolar residents. Scand. J. Psychol. 46, 239-246. doi: 10.1111/j.1467-9450.2005.00453.x

Paola, M. D., Bozzali, M., Fadda, L., Musicco, M., Sabatini, U., and Caltagirone, C. (2008). Reduced oxygen due to high-altitude exposure relates to atrophy in motor-function brain areas. Eur. J. Neurol. 15, 1050-1057. doi: 10.1111/j.14681331.2008.02243.x

Parker, S. M., Erin, J. R., Pryor, R. R., Khorana, P., Suyama, J., Guyette, F. $\mathrm{X}$, et al. (2013). The effect of prolonged light intensity exercise in the heat on executive function. Wilderness Environ. Med. 24, 203-210. doi: 10.1016/j.wem.2013.01.010

Patil, P. G., Apfelbaum, J. L., and Zacny, J. P. (1995). Effects of a cold-water stressor on psychomotor and cognitive functioning in humans. Physiol. Behav. 58, 1281-1286. doi: 10.1016/0031-9384(95)02071-3

Pavlicek, V., Schirlo, C., Nebel, A., Regard, M., Koller, E. A., and Brugger, P. (2005). Cognitive and emotional processing at high altitude. Aviat. Space Environ. Med. $76,28-33$.

Petersen, S. E., and Posner, M. I. (2012). The attention system of the human brain: 20 years after. Annu. Rev. Neurosci. 35, 73-89. doi: 10.1146/annurev-neuro062111-150525

Petrassi, F. A., Hodkinson, P. D., Walters, P. L., and Gaydos, S. J. (2012). Hypoxic hypoxia at moderate altitudes: review of the state of the science. Aviat. Space Environ. Med. 83, 975-984. doi: 10.3357/ASEM.3315.2012

Pickard, J. (2002). The atmosphere and respiration. Fund Aerospace Med. 3, 19-38.

Pilcher, J. J., Nadler, E., and Busch, C. (2002). Effects of hot and cold temperature exposure on performance: a meta-analytic review. Ergonomics 45, 682-698. doi: 10.1080/00140130210158419

Poehlman, E. T., Després, J. P., Bessette, H., Fontaine, E., Tremblay, A., and Bouchard, C. (1985). Influence of caffeine on the resting metabolic rate of exercise-trained and inactive subjects. Med. Sci. Sports Exerc. 17, 689-694.

Qian, S., Sun, G., Jiang, Q., Liu, K., Li, B., Li, M., et al. (2013). Altered topological patterns of large-scale brain functional networks during passive hyperthermia. Brain Cogn. 83, 121-131. doi: 10.1016/j.bandc.2013.07.013

Racinais, S., Gaoua, N., and Grantham, J. (2008). Hyperthermia impairs short-term memory and peripheral motor drive transmission. J. Physiol. 586, 4751-4762. doi: 10.1113/jphysiol.2008.157420

Rahmani, A., Shoae-Hassani, A., Keyhanvar, P., Kheradmand, D., and DarbandiAzar, A. (2013). Dehydroepiandrosterone stimulates nerve growth factor and brain derived neurotrophic factor in cortical neurons. Adv. Pharmacol. Sci. 2013:506191. doi: 10.1155/2013/506191

Rainford, D. J., and Gradwell, D. P. (2006). Ernsting's Aviation Medicine: Hypoxia and Hyperventilation. Boca Raton, FL: Taylor and Francis.

Ramsey, J. D., Burford, C. L., Beshir, M. Y., and Jensen, R. C. (1983). Effects of workplace thermal conditions on safe work behavior. J. Safety Res. 14, 105-114. doi: 10.1016/0022-4375(83)90021-X

Ramsey, J. D., and Kwon, Y. G. (1992). Recommended alert limits for perceptual motor loss in hot environments. Int. J. Ind. Ergon. 9, 245-257. doi: 10.1016/0169-8141(92)90018-U

Rauch, T. M., and Lieberman, H. R. (1990). Tyrosine pretreatment reverses hypothermia-induced behavioral depression. Brain Res. Bull. 24, 147-150. doi: 10.1016/0361-9230(90)90299-F

Regard, M., Oelz, O., Brugger, P., and Landis, T. (1989). Persistent cognitive impairment in climbers after repeated exposure to extreme altitude. Neurology 39, 210-210. doi: 10.1212/WNL.39.2.210

Rektor, I., Kaiiovský, P., Bares, M., Brázdil, M., Streitová, H., Klajblová, H., et al. (2003). A SEEG study of ERP in motor and premotor cortices and in the basal ganglia. Clin. Neurophysiol. 114, 463-471. doi: 10.1016/S1388-2457(02) 00388-7
Rothermundt, M., Peters, M., Prehn, J. H., and Arolt, V. (2003). S100B in brain damage and neurodegeneration. Microsc. Res. Tech. 60, 614-632. doi: 10.1002/jemt.10303

Sakr, H. F., Khalil, K. I., Hussein, A. M., Zaki, M. S., Eid, R. A., and Alkhateeb, M. (2014). Effect of dehydroepiandrosterone (DHEA) on memory and brain derived neurotrophic factor (BDNF) in a rat model of vascular dementia. J. Physiol. Pharmacol. 65, 41-53.

Sharma, V. K., Das, S. K., Dhar, P., Hota, K. B., Mahapatra, B. B., Vashishtha, V., et al. (2014). Domain specific changes in cognition at high altitude and its correlation with hyperhomocysteinemia. PLOS ONE 9:e101448. doi: 10.1371/journal.pone.0101448

Shukitt, B., Burse, R., Banderet, L., Knight, D., and Cymerman, A. (1988). Cognitive Performance, Mood States, and Altitude Symptomatology in 13-21\% Oxygen Environments. Natick, MA: DTIC Document.

Shurtleff, D., Thomas, J. R., Ahlers, S. T., and Schrot, J. (1993). Tyrosine ameliorates a cold-induced delayed matching-to-sample performance decrement in rats. Psychopharmacology (Berl). 112, 228-232. doi: 10.1007/BF02244915

Shurtleff, D., Thomas, J. R., Schrot, J., Kowalski, K., and Harford, R. (1994). Tyrosine reverses a cold-induced working-memory deficit in humans. Pharmacol. Biochem. Behav. 47, 935-941. doi: 10.1016/0091-3057(94) 90299-2

Simmons, S. E., Saxby, B. K., Mcglone, F. P., and Jones, D. A. (2008). The effect of passive heating and head cooling on perception, cardiovascular function and cognitive performance in the heat. Eur. J. Appl. Physiol. 104, 271-280. doi: 10.1007/s00421-008-0677-y

Spitznagel, M. B., Updegraff, J., Pierce, K., Walter, K. H., Collinsworth, T., Glickman, E., et al. (2009). Cognitive function during acute cold exposure with or without sleep deprivation lasting 53 hours. Aviat. Space Environ. Med. 80, 703-708. doi: 10.3357/ASEM.2507.2009

Starcke, K., and Brand, M. (2012). Decision making under stress: a selective review. Neurosci. Biobehav. Rev. 36, 1228-1248. doi: 10.1016/j.neubiorev.2012.02.003

Sun, G., Qian, S., Jiang, Q., Liu, K., Li, B., Li, M., et al. (2013). Hyperthermiainduced disruption of functional connectivity in the human brain network. PLoS ONE 8:e61157. doi: 10.1371/journal.pone.0061157

Sun, G., Yang, X., Jiang, Q., Liu, K., Li, B., Li, L., et al. (2012). Hyperthermia impairs the executive function using the attention network test. Int. J. Hyperthermia 28, 621-626. doi: 10.3109/02656736.2012.705217

Tawatsupa, B., Yiengprugsawan, V., Kjellstrom, T., Berecki-Gisolf, J., Seubsman, S. A., and Sleigh, A. (2013). Association between heat stress and occupational injury among Thai workers: findings of the Thai Cohort Study. Ind. Health 51, 34-46. doi: 10.2486/indhealth.2012-0138

Taylor, L., Fitch, N., Castle, P., Watkins, S., Aldous, J., Sculthorpe, N., et al. (2014). Exposure to hot and cold environmental conditions does not affect the decision making ability of soccer referees following an intermittent sprint protocol. Front. Physiol. 5:185. doi: 10.3389/fphys.2014.00185

Teichner, W. H. (1958). Reaction time in the cold. J. Appl. Psychol. 42, 54. doi: $10.1037 / \mathrm{h} 0049145$

Thomas, J. R., Ahlers, S. T., House, J. F., and Schrot, J. (1989). Repeated exposure to moderate cold impairs matching-to-sample performance. Aviat. Space Environ. Med. 60, 1063-1067.

Tripathi, K., Apte, C., and Mukundan, C. (2005). Temporal adjustments in working memory and vigilance function during 6 days of acclimatization at 10,500 feet altitude. Ind. J. Aerospace. Med. 49, 20-28.

Turner, C. E., Byblow, W. D., and Gant, N. (2015). Creatine supplementation enhances corticomotor excitability and cognitive performance during oxygen deprivation. J. Neurosci. 35, 1773-1780. doi: 10.1523/JNEUROSCI.311314.2015

Virués-Ortega, J., Buela-Casal, G., Garrido, E., and Alcázar, B. (2004). Neuropsychological functioning associated with high-altitude exposure. Neuropsychol. Rev. 14, 197-224. doi: 10.1007/s11065-004-8159-4

Watkins, S. L., Castle, P., Mauger, A. R., Sculthorpe, N., Fitch, N., Aldous, J., et al. (2014). The effect of different environmental conditions on the decisionmaking performance of soccer goal line officials. Res. Sports Med. 22, 425-437. doi: 10.1080/15438627.2014.948624

Watson, P., Enever, S., Page, A., Stockwell, J., and Maughan, R. J. (2012). Tyrosine supplementation does not influence the capacity to perform prolonged exercise in a warm environment. Int. J. Sport Nutr. Exerc. Metab. 22, 363-373. 
Wijayanto, T., Toramoto, S., and Tochihara, Y. (2013). Passive heat exposure induced by hot water leg immersion increased oxyhemoglobin in pre-frontal cortex to preserve oxygenation and did not contribute to impaired cognitive functioning. Int. J. Biometeorol. 57, 557-567. doi: 10.1007/s00484-0120583-1

Wilkinson, R. T., Fox, R. H., Goldsmith, F. R., Hampton, I. F., and Lewis, H. E. (1964). Psychological and physiological responses to raised body temperature. J. Appl. Physiol. 19, 287-291.

Wilson, M. H., Newman, S., and Imray, C. H. (2009). The cerebral effects of ascent to high altitudes. Lancet Neurol. 8, 175-191. doi: 10.1016/S14744422(09)70014-6

Winter, C. D., Whyte, T. R., Cardinal, J., Rose, S. E., O'rourke, P. K., and Kenny, R. G. (2014). Elevated plasma S100B levels in high altitude hypobaric hypoxia do not correlate with acute mountain sickness. Neurol. Res. 36, 779-785. doi: 10.1179/1743132814Y.0000000337

Wright, C. B., Lee, H. S., Paik, M. C., Stabler, S. P., Allen, R. H., and Sacco, R. L. (2004). Total homocysteine and cognition in a tri-ethnic cohort: the Northern Manhattan Study. Neurology 63, 254-260. doi: 10.1212/01.WNL.0000129986.19019.5D

Wurtman, R. J., Hefti, F., and Melamed, E. (1980). Precursor control of neurotransmitter synthesis. Pharmacol. Rev. 32, 315-335.

Xu, L., Wu, Y., Zhao, T., Liu, S. H., Zhu, L. L., Fan, M., et al. (2014). Effect of high altitude hypoxia on cognitive flexibility. Zhongguo Ying Yong Sheng Li Xue Za Zhi 30, 106-109.

Yan, X., Zhang, J., Gong, Q., and Weng, X. (2011). Prolonged highaltitude residence impacts verbal working memory: an fMRI study. Exp. Brain Res. 208, 437-445. doi: 10.1007/s00221-0102494-x

Yeghiayan, S. K., Luo, S., Shukitt-Hale, B., and Lieberman, H. R. (2001). Tyrosine improves behavioral and neurochemical deficits caused by cold exposure. Physiol. Behav. 72, 311-316. doi: 10.1016/S0031-9384(00) 00398-X
Yosipovitch, G., Szolar, C., Hui, X. Y., and Maibach, H. (1996). Effect of topically applied menthol on thermal, pain and itch sensations and biophysical properties of the skin. Arch. Dermatol. Res. 288, 245-248. doi: 10.1007/BF02530092

Zhang, J., Liu, H., Yan, X., and Weng, X. (2011). Minimal effects on human memory following long-term living at moderate altitude. High Alt. Med. Biol. 12, 37-43. doi: 10.1089/ham.2009.1085

Zhang, J., Yan, X., Shi, J., Gong, Q., Weng, X., and Liu, Y. (2010). Structural modifications of the brain in acclimatization to high-altitude. PLoS ONE 5:e11449. doi: 10.1371/journal.pone.0011449

Zhang, Y., Balilionis, G., Casaru, C., Geary, C., Schumacker, R. E., Neggers, Y. H., et al. (2014). Effects of caffeine and menthol on cognition and mood during simulated firefighting in the heat. Appl. Ergon. 45, 510-514. doi: 10.1016/j.apergo.2013.07.005

Conflict of Interest Statement: The authors declare that the research was conducted in the absence of any commercial or financial relationships that could be construed as a potential conflict of interest.

Received: 11 March 2015; Accepted: 20 November 2015; Published: 06 January 2016 Citation: Taylor L, Watkins SL, Marshall H, Dascombe BJ and Foster J (2016) The Impact of Different Environmental Conditions on Cognitive Function: A Focused Review. Front. Physiol. 6:372. doi: 10.3389/fphys.2015.00372

This article was submitted to Exercise Physiology, a section of the journal Frontiers in Physiology

Copyright (c) 2016 Taylor, Watkins, Marshall, Dascombe and Foster. This is an openaccess article distributed under the terms of the Creative Commons Attribution License (CC BY). The use, distribution or reproduction in other forums is permitted, provided the original author(s) or licensor are credited and that the original publication in this journal is cited, in accordance with accepted academic practice. No use, distribution or reproduction is permitted which does not comply with these terms. 